\title{
Pelarangan Mantan Terpidana Korupsi Menjadi Calon Kepala Daerah Agar Menimbulkan Efek Jera
}

\author{
Oleh Jetty Martje Patty ${ }^{1}$ Luchy Edmon Teterissa $^{2}$ \\ Email : jettymartjepatty69@gmail.com ${ }^{1}$; 1dteterissa@gmail.com ${ }^{2}$ \\ ${ }^{1,2}$ Ilmu Hukum, Fakultas Hukum, Universitas Pattimura
}

\begin{abstract}
ABSTRAK
Pemilu adalah proses pergantian kekuasaan secara damai, salah satunya adalah memilih legislator. Pelarangan mantan terpidana untuk menjadi calon legislator menimbulkan polemik dengan gugatan ke Mahkamah Agung karena dikeluarkannya Peraturan Komisi Pemilihan Umum Nomor 20 Tahun 2018 tentang Pencalonan Anggota DPR RI, DPRD Provinsi dan DPRD Kabupaten atau Kota. Disatu sisi ada pendapat pelarangan melanggar hak asasi manusia, tidak sesuai dengan hierarki peraturan perundang-undangan namun ada yang berpendapat bahwa hal ini dapat menimbulkan efek jera baik secara general preventie dan specialle preventive. Korupsi merusak bangsa untuk itu demi kepentingan bangsa, maka pelarangan terhadap mantan terpidana korupsi harus dilakukan. Menurut penulis Peraturan Komisi Pemilihan Umum yang sama arus juga dikeluarkan untuk calon Gubernur, Bupati dan Walikota namun pasti akan digugat ke Mahkamah Agung, untuk itu Undang-undang Nomor 10 Tahun 2016 harus direvisi dan hakim Pegadilan Tindak Pidana Korupsi harus menjatuhkan pidana pencabutan hak menjadi pejabat Negara, legislator, dan kepala daerah minimal 10 tahun agar menimbulkan efek jera.
\end{abstract}

Kata Kunci : Korupsi, Efek Jera, Narapidana 


\begin{abstract}
General Election is a process of peaceful power substitution, one of which is voting for the legislator. Restriction of former sentenced to become legislator candidates creates a polemic with a claim directed to Supreme Court because of the release of General Elections Commission Regulation No. 20 of 2018 about Candidacy of House of Representatives; Provincial Regional House of Representatives; Regency/City Regional House of Representatives' member. On one side, notion towards this restriction said that it's violating human rights, and inconsistent towards the hierarchy of rules, but argued that it can create deterred effect in the form of general preventie and specialle preventie. Corruption destructs society. Hence for society interests, restriction of former sentenced corruptor should be done. According to writer, General Elections Commission Regulation shall also be released towards Governor, Regent /Mayor candidates, but still there will be a claim to Supreme Court, hence Law No. 10 of 2016 should be revised and the judge of corruption court shall condemn them revocation of rights to be state officials, representatives, and regional heads for 10 years minimum to create deterred effect.
\end{abstract}

Keywords: Corruption, Dettered Effect, The Sentenced.

\section{A. Pendahuluan.}

Pemilihan umum merupakan
suatu keharusan bagi suatu negara
yang menamakan dirinya sebagai
negara demokrasi. Sampai sekarang
pemilihan umum masih dianggap
sebagai suatu peristiwa ketatanegaraan

yang penting, karena pemilu melibatkan rakyat secara keseluruhan yang memenuhi syarat-syarat tertentu. Demikian juga melalui pemilihan umum, rakyat dapat menyatakan kehendaknya terhadap garis-garis politik. $^{1}$ Pemilihan umum, dalam

\footnotetext{
${ }^{1}$ Hadjon, Philipus M., dkk, Pengantar Hukum Administrasi Indonesia - Introduction
} 
sebuah negara demokrasi, pemilu merupakan salah satu pilar utama dari sebuah proses akumulasi kehendak masyarakat. Pemilu sekaligus merupakan prosedur demokrasi untuk memilih pemimpin. Diyakini pada sebagian besar masyarakat beradab di muka bumi ini, pemilu adalah mekanisme pergantian kekuasaan (suksesi) yang paling aman, bila dibandingkan dengan cara-cara lain. Sudah barang pasti jika dikatakan, pemilu merupakan pilar utama dari sebuah demokrasi, namun masih banyak calon yang maju dalam pemilu adalah mantan terpidana korupsi. ${ }^{2}$

Bangsa Indonesia ingin terlepas dari jerat korupsi, banyak pejabat Negara belum melaporkan harta kekayaan sebelum dan sesudah menjadi pejabat Negara. Kebiasaan pejabat Negara yang malas dan suka korupsi harus dilawan dengan penanganan yang luar biasa. Indonesia

to the Indonesian Administrative Law, Gajah Mada University Press, Cetakan Kesembilan,. Yogjakarta 2005, hal 31

2 Fahmi, Khairul, Pemilihan Umum dan Kedaulatan Rakyat, PT RajaGrafindo Persada Jakarta 2011. hal 27 sendiri mempunyai Indeks Persepsi Korupsi (IPK) 38 pada tahun 2018, naik 4 point dari tahun 2014, jika dirata-rata maka kenaikan IPK Indonesia 1 pertahun, hal ini dinilai lambat. $^{3}$

Polemik eks narapidana korupsi mengemukan ketika ada caleg eks korupsi yang mau mencalonkan diri namun terkendala dengan PKPU Nomor 20 Tahun 2018 tentang Pencalonan Anggota DPR RI, DPRD Provinsi dan DPRD Kabupaten atau Kota. Mantan terpidana korupsi yang mencalonkan diri melakukan upaya hukum ke Mahkamah Agung karena terjadi pertentangan antara PKPU dengan Undang-undang Nomor 7 Tahun 2017 tentang Pemilu, dalam Putusan Mahkamah Agung Nomor 46 P/HUM/2018 tertangal 13 September 2018 kemudian dihapuskan frasa "Mantan Terpidana Korupsi" Kemudian Komisi Pemilihan Umum segera mengeluarkan surat nomor

https://www.voaindonesia.com/a/indekspersepsi-korupsi-indonesia-naik-buktikeseriusan-pemberantasan-korupsi/4764712.html 
1095/PL.01.04-SD/03/KPU/IX/2018

tertetanggal 19 September 2018 untuk kembali memasukan bakal caleg yang direkomendasikan oleh bawaslu atau pengadilan untuk masuk kedalam daftar caleg.

Bagi penulis pembatalan dan memasukan kembali mantan terpidana korupsi kembali menjadi caleg adalah suatu kemunduran, karena tidak akan menimbulkan efek jera bagi para pelaku, mantan pelaku dan calon pelaku tindak pidana korupsi.

Metode yang dipakai dalam penulisan ini merupakan hasil dari penilitian yuridis normatif, dengan sumber bahan hukum primer, bahan hukum sekunder dan bahan hukum tersier, digunakan analisis bahan hukum secara kuantitatif.

Manfaat dari penulisan ini adalah memberikan pemikiran tentang hubungan pelarangan mantan terpidana korupsi dengan tujuan pemidanaan. Tujuan adalah memberikan pendapat yang berbeda dari sisi tujuan pemidanaan untuk menimbulkan efek jera bagi mantap terpidana korupsi.
Permasalahan yang mucul adalah apakah dapat dilakukan pelarangan kepada calon kepala daerah pada Tahun 2020, dengan tujuan untuk menimbulkan efekjera, sehingga manfaat yang diperoleh dari penulisan ini padangan yang berbeda dengan tulisan-tulisan yang mendukung tidak boleh ada pelarangan hak politik mantan terpidana korupsi

\section{B. Hasil dan Pembahasan}

Sanksi yang untuk memperkuat norma hukum adalah dengan sanksi pidana merupakan suatu benteng terakhir. Artinya, sanksi pidana baru digunakan apabila sanksi hukum yang lain dirasakan tidak mampu untuk untuk menjaga atau memperkuat norma hukum yang telah ada. Hal ini dikenal dengan istilah " Ultimum Remedium".4 Penanganan korupsi harus dilakukan dengan luar biasa karena tindak pidana korupsi tergolong dalam hukum pidana khusus yang

4 Bisarida dkk, "Komparasi Mekansime Penyelasaian Sengketa Pemilu di Beberapa Negara Penganut Paham Demokrasi”, Jurnal Konstitusi, Vol. 9, Nomor 3, 2012, hal.538. 
dapat menyampingkan peraturan pidana yang umum yang diatur dalam Kitab Undang-undang Hukum Pidana, penyimpangan dapat didasarkan pada asas preferensi hukum (Lex specialis derogat legi generali) peraturan yang khusus menyampingkan peraturan yang umum. ${ }^{5}$

$\begin{array}{lcr}\text { Dalam } & \text { Rancangan } & \text { Kitab } \\ \text { Undang-undang } & \text { Hukum } & \text { Pidana } \\ \text { (selanjutnya disebut RUU } & \text { KUHP), } \\ \text { Pasal } 58 \text { huruf (a) menyebutkan bahwa }\end{array}$

Faktor yang memperberat pidana meliputi:

a. pejabat yang melakukan Tindak Pidana sehingga melanggar kewajiban jabatan yang khusus atau melakukan Tindak Pidana dengan menyalahgunakan kewenangan,

\footnotetext{
${ }^{5}$ Erwin Ubwarin et al.
} Mekanisme Pengembalian Kerugian Negara oleh Terpidana yang Meninggal Dunia Pasca Putusan Mahkamah Konstitusi Nomor 25/PUU-XIV/2016. Jurnal Muara Ilmu Sosial, Humaniora, dan Seni. hal 51 kesempatan, atau sarana yang diberikan kepadanya karena jabatan;

RUU KUHP jelas mengatakan bahwa orang yang melanggar kewajiban jabatan, dengan menyalahgunakan kewenangan, kesempatan, atau sarana ada padanya harus diberikan pemberatan, dan menyalahgunakan kewenangan, kesempatan, atau sarana yang diberikan kepadanya karena jabatan adalah rumusan jenis tindak pidana dalam tindak pidana korupsi. Seperti dijelaskan diatas bahwa Undang-undang Nomor 7 Tahun 2017 tentang Pemilu tidak mengakomodir tentang pelaranggan mantan terpidana korupsi menjadi calon legislator, padahal calon legislator merupakan calon penyelenggara negara, dan sebelumnya pada jabatannya sebelumnya ia dengan sah dan meyakinkan hakim terbukti bersalah dalam pengadilan tindak pidana korupsi. Apakah negara harus memberikan kesempatan kedua kepada orang-orang yang terbukti melakukan 
tindakan yang dapat dikualifikasikan dengan perbuatan dengan pemberatan, menurut penulis tidak.

Bahwa hak untuk memilih dan dipilih dalam lembaga perwakilan rakyat sebagaimana terdapat dalam kelompok hak-hak politik, ekonomi, sosial, dan budaya, bukan merupakan suatu yang menghalagi penjatuhan pidana ataupun pelaranggan mantan terpidana korupsi menjadi calon legislator, kepala daerah atau pejabat negara yang lain, karena bukan termasuk dalam hak asasi manusia yang tidak dapat dikurangi dalam keadaan apapun atau nonderorable rights. Pasal 73 Undang-undang Nomor 39 Tahun 1999 tentang Hak Asasi Manusia jelas mengatakan bahwa

Hak dan kebebasan yang diatur dalam Undang-undang ini hanya dapat dibatasi oleh dan berdasarkan undang-undang, semata-mata untuk menjamin pengakuan dan penghormatan terhadap hak asasi manusia serta kebebasan dasar orang lain, kesusilaan, ketertiban umum, dan kepentingan bangsa Pandangan muncul bahwa pelarangan mantan terpidana korupsi melakukan korupsi melanggar hak asasi manusia, menurut penulis hal itu tidak mendasar, selain alasan diatas kita dapat melihat alasan pengenaan kebiri bagi pelaku kejahatan, dan pemberlakuan pidana mati, hukuman kebiri dan penjatuhan pidana mati untuk menimbulkan efek jera baik bagi pelaku maupun mempunyai efek preventif.

Bagi penulis pelarangan mantan terpidana korupsi adalah untuk kepentingan bangsa, tidak melanggar hak asasi manusia, efek jera harus ada bagi mantan terpidana korupsi, terpidana korupsi dan calon terpidana korupsi, dengan begitu orang menjadi takut melakukan korupsi. Pada Undang-undang nomor 7 Tahun 2017 tentang Pemilu sendiri mengakui dan mengatur bahwa seorang terpidana korupsi tidak dapat menjadi calon presiden dan wakil presiden Pasal 169 ayat 4 yang berbunyi "tidak pernah 
mengkhianati negara serta tidak pernah melakukan tindak pidana korupsi dan tindak pidana berat lainnya.Pembuat undang-undang pemilu sadar bahwa seorang mantan terpidana korupsi tidak boleh menjadi Presiden, kemudian kenapa untuk pejabat negara yang lain dibiarkan mantan terpidana korupsi dapat menjadi calon.

Pemilihan umum akan terulang pada Tahun 2020, kali ini tentang pemilihan Gubernur, Bupati dan Walikota, ada 270 Daerah yang akan melakukan pemilihan umum kepala daerah (PILKADA). ${ }^{6}$ Kita akan memilih calon terbaik untuk menjadi pemimpin kita. Undang-undang Nomor 10 Tahun 2016 tentang Perubahan Kedua atas Undang-undang Nomor 1 TAHUN 2015 tentang Penetapan Peraturan Pemerintah Pengganti Undang-Undang Nomor 1 TAHUN 2014 tentang Pemilihan Gubernur, Bupati, dan Walikota menjadi Undang-Undang, dipakai sebagai landasan hukum untuk

\footnotetext{
${ }^{6}$ https://news.detik.com/berita/d4596501/ini-270-daerah-yang-gelar-pilkadaserentak-2020
}

menyelenggarakan PILKADA, dan jika Komisi Pemilihan Umum mengeluarkan PKPU untuk melarang calon Gubernur, Bupati dan Walikota yang mantan terpidana korupsi pasti akan digugat di Mahkamah Agung kembali. Menurut penulis Undangundang ini harusnya di revisi.

Majelis Hakim Tindak Pidana Korupsi harus berani untuk memberikan putusan untuk mencabut hak menjadi pejabat Negara atau menjadi calon anggota legislator atau menjadi calon Gubernur, Bupati dan Walikota minimal 10 Tahun. Dengan begitu akan menimbulkan efek jera. Menurut penulis ada beberapa alasan yaitu :

a. pelarangan mantan terpidana korupsi menimbulkan keadilan dan merupakan tindakan pembalasan yang setimpal

b. pelarangan mantan terpidana korupsi merupakan tindakan preventif baik secara general untuk semua orang dan secara spesialis untuk 


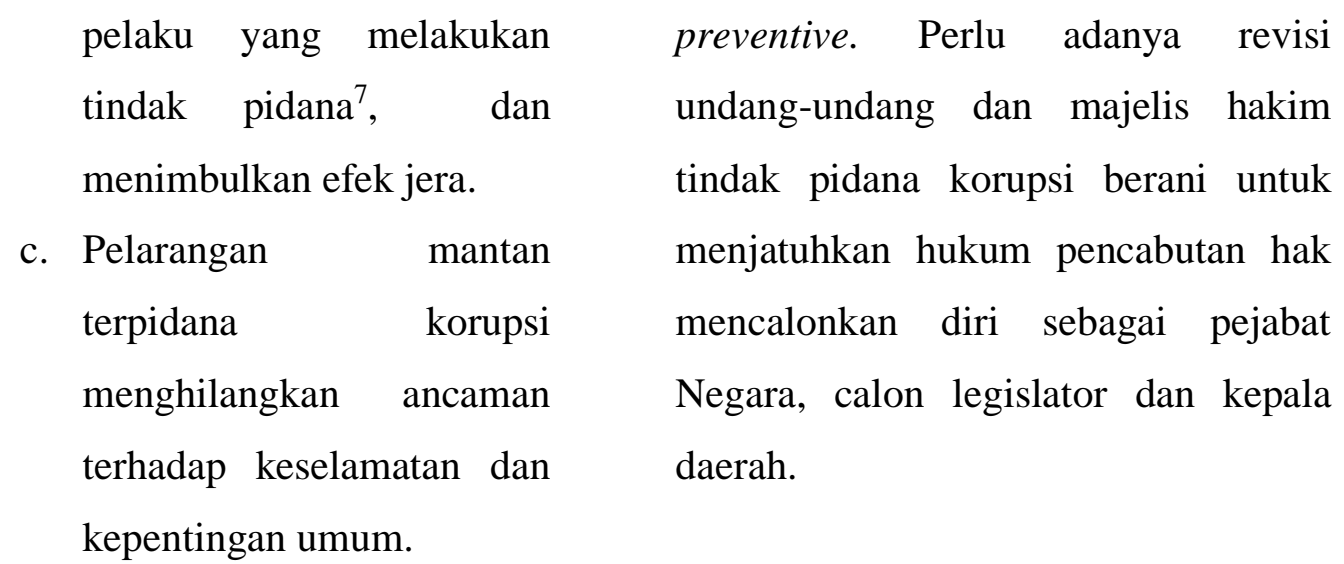

\section{Penutup}

Pemilihan umum menghasilkan para pemimpin yang menjadi pejabat Negara yang menjalankan fungsi dan wewenang untuk mensejaterahkan masyarakat namun jika calon yang maju dalam pesta demokrasi merupakan mantan terpidana korupsi menimbulkan masalah, karena dia bisa saja mengulangi kejahatan yang sama, karena tidak ada undang-undang yang melarang calon Gubernur, Bupati dan Walikota mantan terpidana korupsi untuk mencalonkan diri, perlu melarang mantan terpidana korupsi untuk menjadi mencalonkan diri, agar menimbulkan efek jera baik secara general preventie dan specialle

\footnotetext{
${ }^{7}$ W. Prodjodikoro, Asas-Asas Hukum Pidana, Jakarta: Rajawali Press, 1981, hal. 27
} 


\section{Daftar Pustaka}

dkk, B. (2012). Komperasi Mekanisme Penyelesaian Sengketa Pemilu di Beberapa Negara Penganut Paham Demokrasi. Jurnal Konstitusi , 538.

Erwin Ubwarin, Yonna B. Salamor. (2017). Mekanisme Pengembalian Kerugian Negara oleh Terpidana yang Meninggal Dunia Pasca Putusan Mahkamah Konstitusi Nomor 25/PUU-XIV/2016. Jurnal Muara Ilmu Sosial, Humaniora, dan Seni , 51-57.

Fahmi, K. (2011). Pemilihan Umum dan Kedaulatan Rakyat. Jakarta: PT Raja Grafindo Persada.

Hadjon, P. M. (2005). Pengantar Hukum Administrasi Indonesia-IndonesiaIntroduction to the Indonesia Administrative Law. Yogyakarta: Gajah Mada University Press, Cetakan Kesembilan.

Prodjodikoro, W. (1981). Asas-Asas Hukum Pidana. Jakarta: Rajawali Press.

Web

https://news.detik.com/berita/d-4596501/ini-270-daerah-yang-gelar-pilkada-serentak$\underline{2020}$

https://www.voaindonesia.com/a/indeks-persepsi-korupsi-indonesia-naik-buktikeseriusan-pemberantasan-korupsi-/4764712.html 